\title{
Synthesis and molecular docking of pyrimidine incorporated novel analogue of 1,5-benzodiazepine as antibacterial agent
}

\author{
APOORVA MISRA ${ }^{\mathrm{a}}$, SWAPNIL SHARMA $^{\mathrm{b}, *}$, DIVYA SHARMA $^{\mathrm{b}}$, SUNIL DUBEY $^{\mathrm{c}}$, \\ ACHAL MISHRA $^{\mathrm{b}}$, DHARMA KISHORE ${ }^{\mathrm{a}}$ and JAYA DWIVEDI ${ }^{\mathrm{a}}$

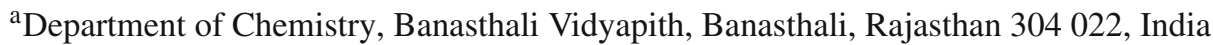 \\ ${ }^{b}$ Department of Pharmacy, Banasthali Vidyapith, Banasthali, Rajasthan 304 022, India \\ ${ }^{\mathrm{c}}$ Department of Pharmacy, Birla Institute of Technology and Science, Pilani, Pilani, Rajasthan 333 031, India \\ E-mail: skspharmacology@gmail.com
}

MS received 24 October 2017; revised 6 February 2018; accepted 13 February 2018; published online 9 March 2018

\begin{abstract}
A one-pot protocol involving nitrile-derived amidoxime of 1,5-benzodiazepine to synthesize its novel pyrimidine derivatives using DMAD and DABCO catalyst under microwave conditions has been described. The antibacterial activity of the synthesized compounds was examined against Gram-positive S. aureus and Gram-negative E. coli using broth micro-dilution assay. Low $\mathrm{IC}_{50}$ values for the synthesized compounds indicated their potential as antibacterial agents. Further, field emission scanning electron microscopic study and cell membrane leakage study ascertained that the test compounds have ability to cause cell lysis via bacterial cell membrane rupture and disintegration. In addition, molecular docking studies suggested that test compounds may act through bacterial DHFR inhibition.
\end{abstract}

Keywords. 1, 5-benzodiazepine; pyrimidine; domino synthesis; antibacterial activity.

\section{Introduction}

There have been several major advances in synthetic organic chemistry during the last decade, including multicomponent, mechanochemical, green, combinatorial and bio-organic syntheses. Domino reactions are extremely efficient means of two or more bond forming reactions in one step. ${ }^{1}$ Employing one-pot domino approach would allow one to create novel pharmacophores from simpler molecules using a group of consistent chemical reactions with high stereocontrol in a fast, proficient and atom-economical manner.

Benzodiazepine $^{2 \mathrm{a}, \mathrm{b}}$ is a psychoactive nucleus whose derivatives have attracted significant consideration of researchers, because of their biological and therapeutic activities. Various members of this family are extensively used as anticonvulsant, ${ }^{3}$ antianxiety, ${ }^{4}$ analgesic, sedative, anti-depressant, hypnotic, ${ }^{5}$ anti-inflammatory, ${ }^{6}$ antiviral ${ }^{7}$ and anti-HIV agents. ${ }^{8}$ Some benzodiazepines showed activity as muscle relaxant, ${ }^{9}$ anticoagulant, antiobesity, antiulcer, calcium channel blockers, ${ }^{10}$

\footnotetext{
*For correspondence
}

cholecystokinin antagonists, ${ }^{11}$ endothelin antagonist, thrombopoietin receptor agonist, and vasopressin receptor antagonist. ${ }^{12}$

Pyrimidines are extensively used as anticancer, ${ }^{13}$ antiviral, ${ }^{14}$ anti-mycobacterial, ${ }^{15}$ anti-inflammatory, ${ }^{16}$ analgesic, ${ }^{17}$ antiallergic, ${ }^{18}$ anti-HIV, ${ }^{19}$ antimicrobial, anti-avian influenza virus (H5N1), ${ }^{20}$ anti-arrhythmic, ${ }^{21}$ serotonin 5-HT6 receptor antagonist, ${ }^{22}$ hepatitis-A virus (HAV) and herpes simplex virus type-1 (HSV-1) inhibitor, ${ }^{23}$ etc. Pyrimidine analogs have been also demonstrated anti-conceptive, platelet aggregation inhibitors, antagonists and anti-parkinson activities. ${ }^{24}$

Worldwide, development of drug resistance is becoming a serious threat in antimicrobial therapy and considered as major public health concern. Antibacterial properties of pyrimidine and fused pyrimidine derivatives are well-known, and some pyrimidine-containing antibiotics such as Trimethoprim, Piromidic Acid, Tetroxoprim, Metioprim are among the most widely prescribed antimicrobials. ${ }^{25}$ It is an established fact that DHFR is a central enzyme actively involved in the production of purine and pyrimidine bases. Therefore, DHFR has become a reliable key target in antimicrobial therapy. ${ }^{26}$ 
In recent years, synthesis of heterocycles from active nitrile substrates, ${ }^{27}$ such as enaminonitriles, ${ }^{28}$ amidoximes, imidate esters, nitrilium ion intermediates derived from nitriles has been a fast-emerging subject and has attracted the attention of chemists due to its widespread application. Herein, we report an efficient, one-pot domino approach for the synthesis of pyrimidine-incorporated 1,5-benzodiazepine (6) analogue through its nitrile-derived amidoxime (5) and to examine its antibacterial activity. In view of this, an attempt has been made to incorporate the pyrimidine nucleus onto the 1,5-benzodiazepine and explore its anti-bacterial activity.

\section{Experimental}

\subsection{Materials}

High purity reagents and solvents were purchased from Sigma Aldrich, USA and used as received. The purity of the compounds was checked by elemental analysis and thin-layer chromatography. Elemental analyses for compounds were obtained using CHNS analyzer, Perkin Elmer, USA. Purity of the compounds was routinely examined using precoated silica gel 60 F254 plates $(200$ mm; Merck, Darmstadt, Germany). All melting points were measured with a capillary apparatus and are uncorrected. All the compounds were characterized by IR, ${ }^{1} \mathrm{H}$ NMR and mass spectra. ${ }^{1} \mathrm{H}$ NMR, ${ }^{13} \mathrm{C}$ NMR spectra were recorded on a Jeol Resonance/Bruker Ascend $400 \mathrm{MHz}$ spectrometer. The chemical shift was recorded in ppm with TMS as internal reference. IR spectra were recorded in $\mathrm{KBr}$ on pellet using Cary 660 FTIR spectrophotometer (Agilent Tech.). Mass spectra were recorded on Waters, QT-OF micromass (LCMS) mass spectrometer (6 $\mathrm{kV}, 10 \mathrm{mB}$ ) using Argon/Xenon gas. Field emission scanning electron microscopy (FE-SEM) was done on Tescan, Mira 3.

\subsection{Synthesis}

The target compounds were synthesized following the schemes given below.

\section{2a Synthesis of (Z)-2-benzoyl-3-(dimethylamino)acr} ylonitrile (2): The mixture of benzoylacetonitrile $1(0.01$ $\mathrm{mol})$ and $\mathrm{N}, \mathrm{N}$-dimethylformamide dimethylacetal $(15 \mathrm{~mL})$ was refluxed for $4.5 \mathrm{~h}$ and concentrated. The residue was triturated with hexane, filtered and washed with hexane to give compound 2. Obtained as a yellow solid; Yield: 68\%; M.p.: $191-193^{\circ} \mathrm{C}$. IR $\left(\mathrm{KBr}, \nu / \mathrm{cm}^{-1}\right)$ : 3063, 2254, 1674, $1645,1540,1320 .{ }^{1} \mathrm{H}$ NMR $(\delta$, ppm in DMSO-d 6$): 3.60(\mathrm{~s}$, $6 \mathrm{H}), 6.64(\mathrm{~s}, 1 \mathrm{H}), 7.42-7.65(\mathrm{~m}, 5 \mathrm{H}) .{ }^{13} \mathrm{C}$ NMR $(\delta, \mathrm{ppm}$ in DMSO- $\mathrm{d}_{6}$ ): $189.80,160.62,137.40,135.45,131.39,129.80$, 119.80, 81.79, 51.70. Anal. calc. for $\mathrm{C}_{12} \mathrm{H}_{12} \mathrm{~N}_{2} \mathrm{O}: \mathrm{C} 71.98, \mathrm{H}$ 6.04, N 13.99\%. Found: C 71.94, H 6.09, N 13.91\%.
$2.2 \mathrm{~b}$ Synthesis of 4-phenyl-1H-benzo[b][1,4]diazep ine-3-carbonitrile (4): A mixture of o-phenylenediamine $3(0.01 \mathrm{~mol})$, dimethylaminomethylene ketone derivative 2 $(0.01 \mathrm{~mol})$ and ethanol was heated under reflux for $6 \mathrm{~h}$. The solvent was removed by rotary evaporation and the reaction was quenched in crushed ice. It was extracted with chloroform, washed with water and dried $\left(\mathrm{Na}_{2} \mathrm{SO}_{4}\right)$ to give 4. Obtained as a brown solid; Yield: $64 \%$; M.p.: $170^{\circ} \mathrm{C}$. IR $\left(\mathrm{KBr}, \nu / \mathrm{cm}^{-1}\right): 3321,3074,2190,1623,1563,1317 .{ }^{1} \mathrm{H}$ NMR $(\delta$, ppm in DMSO-d 6 ): 7.94-7.89 (s, 2H), 7.55-6.89 $(\mathrm{m}, 7 \mathrm{H}), 5.36(\mathrm{~s}, 1 \mathrm{H}), 4.14(\mathrm{~s}, 1 \mathrm{H}) .{ }^{13} \mathrm{C}$ NMR $(\delta, \mathrm{ppm}$ in DMSO-d 6 ):167.70, 161.40, 141.67, 135.45, 131.39, 129.80, 125.45, 117.40, 111.20, 79.20. Anal. calc. for $\mathrm{C}_{16} \mathrm{H}_{11} \mathrm{~N}_{3}$ : C 78.35, H 4.52, N 17.13\%. Found: C 78.31, H 4.55, N 17.10\%.

2.2c Synthesis of N-hydroxy-4-phenyl-1H-benzo[b] [1,4]diazepine-3-carboxamidine (5): Hydroxylamine hydrochloride $(29.1 \mathrm{mmol})$, sodium carbonate $(29.1 \mathrm{~mm}$ ol) were dissolved in $25.0 \mathrm{~mL}$ water. Then compound $\mathbf{5}$ ( $29.1 \mathrm{mmol}$ ) in $25 \mathrm{~mL}$ ethanol was added to it. The reaction mixture was irradiated with an ultrasound probe for 15-30 $\min$ at $55^{\circ} \mathrm{C}$ (TLC monitoring). Concentrated by rotary evaporation at reduced pressure to afford a mixture of colorless oil which was then dissolved in $50 \mathrm{~mL}$ of dichloromethane, dried $\left(\mathrm{Na}_{2} \mathrm{SO}_{4}\right)$, filtered and solvent was removed under reduced pressure. Further, it was recrystallized from chloroformhexane to give compound 5. Obtained as a brown solid; Yield: 69\%; M.p.: $117^{\circ} \mathrm{C}$. IR (KBr, $\left.v / \mathrm{cm}^{-1}\right)$ : $3445,3352,1642$, 1446. ${ }^{1} \mathrm{H}$ NMR $(\delta$, ppm in DMSO-d 6 ): $8.64(\mathrm{~s}, 2 \mathrm{H}), 7.91-7.86$ (s, 2H), 7.59-6.74 (m, 7H), $4.62(\mathrm{~s}, 1 \mathrm{H}), 3.86(\mathrm{~s}, 1 \mathrm{H}), 1.79$ (s, $1 \mathrm{H}) .{ }^{13} \mathrm{C}$ NMR $(\delta$, ppm in DMSO-d 6 ): $163.04,154.26,139.80$, 135.45, 130.30, 129.80, 127.40, 125.45, 115.45, 97.40.Anal. calc. for $\mathrm{C}_{16} \mathrm{H}_{14} \mathrm{~N}_{4} \mathrm{O}$ : C 69.05, H 5.07, N 20.13\%. Found: C 69.08 , H 5.03, N $20.17 \%$.

2.2d Synthesis of 5,6-dihydroxy-2-(4-phenyl-1H-ben zo[b][1,4]diazepin-3-yl]-pyrimidine-4-carboxylic acid methyl ester (6): To DABCO $(0.09 \mathrm{mmol})$ and amidoxime $5(0.9 \mathrm{mmol})$ at $-10^{\circ} \mathrm{C}$ in dioxane, DMAD was added. Resulting reaction mixture was stirred for $15 \mathrm{~min}$ and warmed to room temperature then subjected to microwave irradiation in two stage sequence (stage $1,80^{\circ} \mathrm{C}, 5-10 \mathrm{~min}$; stage $2,120^{\circ} \mathrm{C}$ and $20 \mathrm{~min}$ ). The solvent was removed by rotary evaporation and residue was purified by flash column chromatography to afford $\mathbf{6}$. Obtained as a brown solid; Yield: $54 \%$; M.p.: $120^{\circ} \mathrm{C}$. IR $\left(\mathrm{KBr}, \nu / \mathrm{cm}^{-1}\right)$ : 3618 , $3335,2975,1742,1684,1503,1249 .{ }^{1} \mathrm{H}$ NMR $(\delta, \mathrm{ppm}$ in DMSO-d $\left.\mathrm{d}_{6}\right): 12.36(\mathrm{~s}, 1 \mathrm{H}) ; 8.02(\mathrm{~s}, 2 \mathrm{H}) ; 7.57-6.74(\mathrm{~m}$, $7 \mathrm{H}) ; 5.56(\mathrm{~s}, 1 \mathrm{H}) ; 4.81(\mathrm{~s}, 1 \mathrm{H}) ; 3.83(\mathrm{~s}, 4 \mathrm{H}) .{ }^{13} \mathrm{C} \mathrm{NMR}(\delta$, ppm in DMSO-d $\left.{ }_{6}\right): 167.40,151.67,144.26,137.19,135.45$, $130.62,127.21,125.20,122.17,111.79,65.39$. Anal. calc. for $\mathrm{C}_{21} \mathrm{H}_{16} \mathrm{~N}_{4} \mathrm{O}_{4}$ : C 64.94, H 4.15, N 14.43\%. Found: C 64.97, H 4.12, N $14.46 \%$. m/z: 388.0461 .

2.2e Synthesis of (Z)- 3-(dimethylamino)acryloyl cya nide (8): The mixture of pyruvonitrile $7(0.01 \mathrm{~mol})$ and $\mathrm{N}, \mathrm{N}$-dimethylformamide dimethylacetal $(15 \mathrm{~mL})$ was heated 
<smiles>CN(C)C=C(C#N)C(=O)c1ccccc1</smiles>

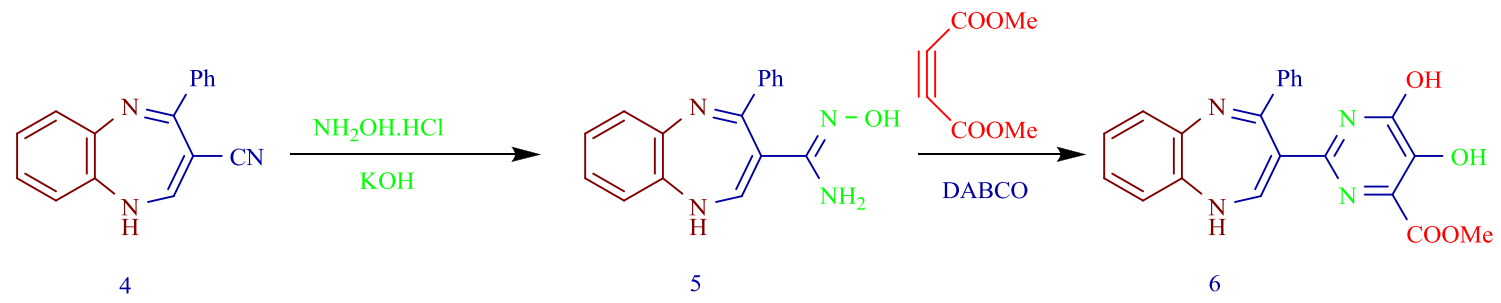

Scheme 1. Synthesis of pyrimidine derivatives of 1,5-benzodiazepine from benzoylacetonitrile.

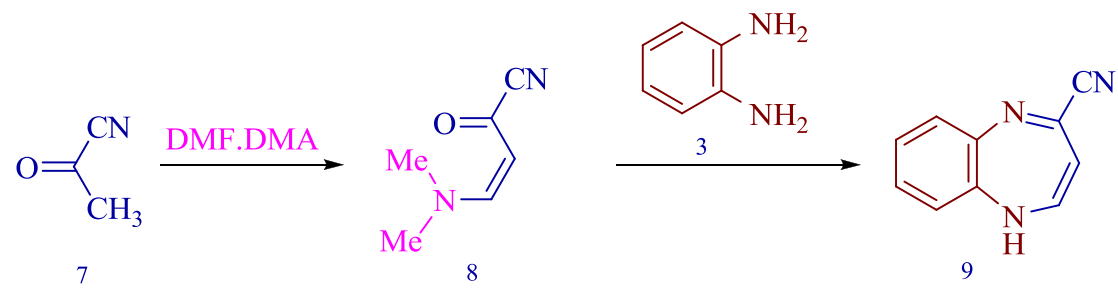

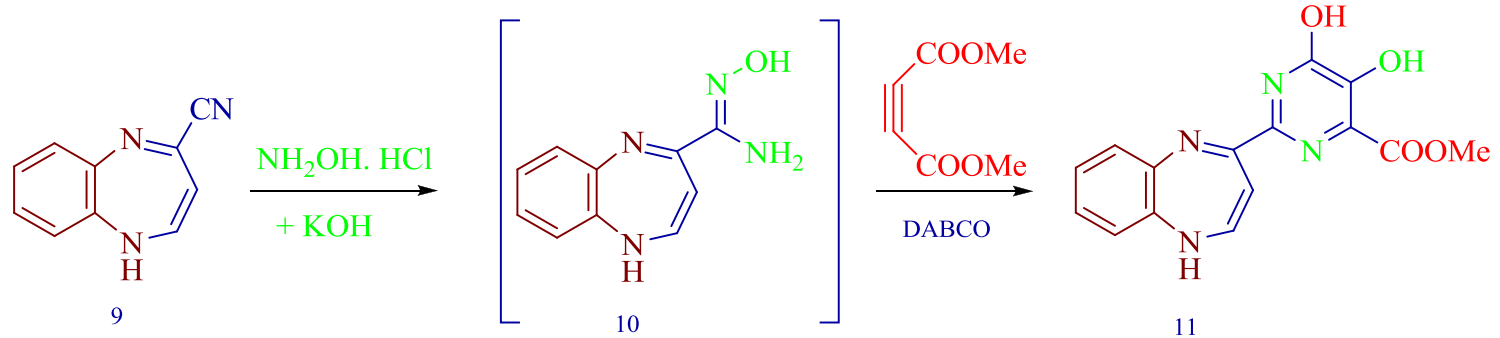

Scheme 2. Synthesis of pyrimidine derivatives of 1,5-benzodiazepine from pyruvonitrile.

under reflux for $4.5 \mathrm{~h}$ and then concentrated. The residue was triturated with hexane, filtered and washed with hexane to give 8. Obtained as yellow solid; Yield 69\%, M.p: $102^{\circ} \mathrm{C}$. IR (KBr, $\left.\nu / \mathrm{cm}^{-1}\right): 2361,2361,1702,1648,1215 .{ }^{1} \mathrm{H}$ NMR $(\delta$, ppm in DMSO-d 6 ): 6.89-6.82 (d, 1H); 5.30-5.29 (d, 1H); $3.89(\mathrm{~s}, 6 \mathrm{H}) .{ }^{13} \mathrm{C} \mathrm{NMR}(\delta, \mathrm{ppm}$ in DMSO-d 6$): 185.45,167.40$, 119.80, 111.79, 39.68. Anal. calc. for $\mathrm{C}_{6} \mathrm{H}_{8} \mathrm{~N}_{2} \mathrm{O}: \mathrm{C} 58.05, \mathrm{H}$ $6.50, \mathrm{~N} 22.57 \%$. Found: C 58.07, H 6.47, N 22.53\%.

2.2f Synthesis of 5H-benzo[b][1,4]diazepine-2-car bonitrile (9): A mixture of o-phenylenediamine 3 (0.01 mol), dimethylaminomethylene ketone derivative 8 (0.01 mol) and ethanol was refluxed for $6 \mathrm{~h}$. The solvent was removed by rotary evaporation and the reaction was quenched in crushed ice. Product was then extracted in chloroform and dried (over $\left(\mathrm{Na}_{2} \mathrm{SO}_{4}\right)$ to give 9 . Obtained as green solid; Yield 68\%, M.p: $148{ }^{\circ} \mathrm{C}$. IR (KBr, $\left.v / \mathrm{cm}^{-1}\right)$ : 3025, 2833, 2213, $1602,1507,1278 .{ }^{1} \mathrm{H}$ NMR $\left(\delta\right.$, ppm in DMSO- $\left.\mathrm{d}_{6}\right): 7.23-6.75$ $(\mathrm{m}, 4 \mathrm{H}) ; 5.02-5.01(\mathrm{~d}, 1 \mathrm{H}) ; 4.51-4.50(\mathrm{~d}, 1 \mathrm{H}) ; 4.14(\mathrm{~s}, 1 \mathrm{H})$. ${ }^{13} \mathrm{C}$ NMR $(\delta, \mathrm{ppm}$ in DMSO-d 6 ): 141.18, 137.19, 127.21,
125.20, 117.22, 111.20, 79.20.Anal. calc. for $\mathrm{C}_{10} \mathrm{H}_{7} \mathrm{~N}_{3}$ : C 70.99, H 4.17, N 24.84\%. Found: C 70.98, H 4.15, N 24.87\%.

2.2g Synthesis of (Z)- $N^{\prime}$-hydroxy-1H-benzo[b][1,4] diazepine-4-carboxamidine (10): Hydroxylamine hydro chloride $(29.1 \mathrm{mmol})$, sodium carbonate $(29.1 \mathrm{mmol})$ were dissolved in $25.0 \mathrm{~mL}$ water. Then compound $\mathbf{9}(29.1 \mathrm{mmol})$ in $25 \mathrm{~mL}$ ethanol was added to it. The reaction mixture was irradiated with an ultrasound probe for $15-30 \mathrm{~min}$ at $55^{\circ} \mathrm{C}$ (TLC monitoring). Concentrated by rotary evaporation at reduced pressure to afford a mixture of colorless oil which were then dissolved in $50 \mathrm{~mL}$ of dichloromethane, dried $\left(\mathrm{Na}_{2} \mathrm{SO}_{4}\right)$, filtered and solvent was removed under reduced pressure. Further, it was recrystallized from chloroform-hexane to give compound $\mathbf{1 0}$.

2.2h Synthesis of methyl-2-(1H-benzo[b][1,4]diaze pin-4-yl)-5,6-dihydroxy pyrimidine-4-carboxylate (11): To DABCO (0.09 mmol) and amidoxime 10 (0.9 mmol) at $-10^{\circ} \mathrm{C}$ in dioxane, DMAD was added. Resulting reaction mixture was stirred for $15 \mathrm{~min}$ and warmed to room 


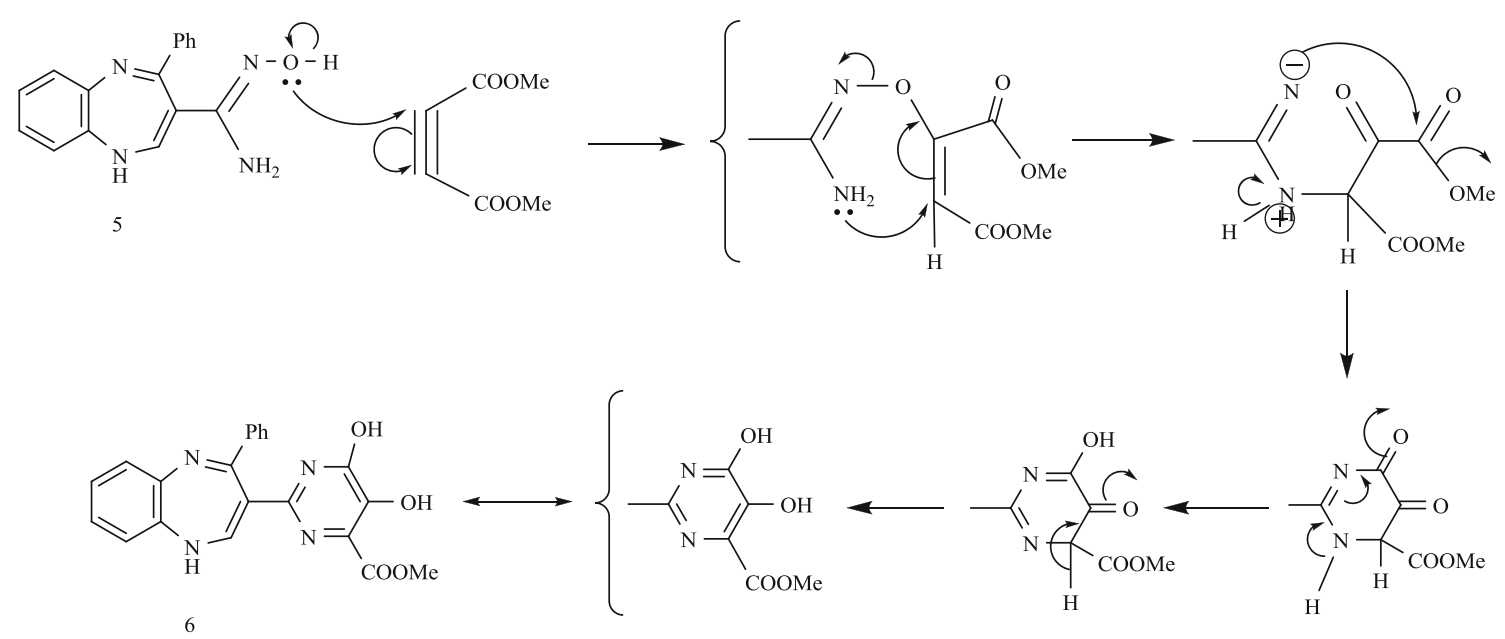

Scheme 3. Mechanism of formation of pyrimidine derivative of 1,5-benzodiazepine from amidoxime.

temperature then subjected to microwave irradiation in two stage sequence (stage $1,80^{\circ} \mathrm{C}, 5-10 \mathrm{~min}$; stage $2,120^{\circ} \mathrm{C}$ and $20 \mathrm{~min}$ ). The solvent was removed by rotary evaporation and residue was purified by flash column chromatography to afford 11. Obtained as black solid; Yield 52\%, M.p.: $142^{\circ} \mathrm{C}$. IR $\left(\mathrm{KBr}, v / \mathrm{cm}^{-1}\right): 3445,3348,3223,1707,1599,1512$, $1264,1166,1091 .{ }^{1} \mathrm{H}$ NMR $(\delta$, ppm in DMSO-d 6 ): 11.79 (s, $1 \mathrm{H})$; 7.23-6.75 (s, 4H); $5.45(\mathrm{~s}, 1 \mathrm{H})$; 5.02-5.01 (d, 1H); 4.51$4.50(\mathrm{~d}, 1 \mathrm{H}) ; 4.14(\mathrm{~s}, 4 \mathrm{H}) .{ }^{13} \mathrm{C}$ NMR $(\delta, \mathrm{ppm}$ in DMSO-d 6 ): 160.62 , 153.04, 141.18, 137.19, 127.21, 125.20, 117.22, 79.20, 65.39. Anal. calc. for $\mathrm{C}_{15} \mathrm{H}_{12} \mathrm{~N}_{4} \mathrm{O}_{4}$ : C 57.69, H3.87, N 17.94\%. Found: C 57.71, H 3.86, N 17.96\%. m/z: 312.9862.

\subsection{Antibacterial activity}

The antibacterial activity of the compound was evaluated against Staphylococcus aureus (MTCC 9886) and Escherichia coli (MTCC 433). Lyophilized bacterial cultures were procured from Microbial Type Culture Collection, Chandigarh, India and were cultured and maintained using nutrient broth medium.

2.3a Determination of half maximal inhibitory concentration $\left(I C_{50}\right)$ : Antibacterial susceptibility testing was done using broth micro-dilution assay and $\mathrm{IC}_{50}$ of the test compound was determined. For each set of experiment, strains were sub-cultured for $24 \mathrm{~h}$ at $37 \pm 2{ }^{\circ} \mathrm{C}$. Culture media was prepared from nutrient broth autoclaved at $121^{\circ} \mathrm{C}$ for $20 \mathrm{~min}$ at $15 \mathrm{lb}$ pressure. Different concentrations of test compound and standard (ampicillin) were prepared in DMSO. Bacterial suspension $(20 \mu \mathrm{L})$ adjusted to approximately $10^{9}$ cell $/ \mathrm{mL}$ was added into different culture tubes containing broth media. Further, test and standard compounds were added into different culture tubes and incubated at $37^{\circ} \mathrm{C}$ for $18 \mathrm{~h}$. After incubation, samples were analyzed for bacterial growth inhibition using UV-Visible spectrophotometry at $600 \mathrm{~nm}$. All the experiments were carried out in triplicates and $\mathrm{IC}_{50}$ was estimated as mean concentration. 2.3b Field emission scanning electron microscope (FE-SEM) study: Ability of test compound in inducing morphological changes in bacterial cells was analyzed by FE-SEM and compared with control sample (untreated bacterial suspension). Briefly, bacterial strains; $S$. aureus and $E$. coli were treated with $200 \mu \mathrm{g} / \mathrm{mL}$ and $300 \mu \mathrm{g} / \mathrm{mL}$ of test compound, respectively, and were incubated for $6 \mathrm{~h}$. After, incubation sample tubes were centrifuged at $1000 \mathrm{rpm}$ for 20 min. Pellets so obtained were washed with phosphate buffered saline (PBS) three times and pre-fixed with $2.5 \%$ glutaraldehyde for $20 \mathrm{~min}$. The pre-fixed cells were washed again with PBS and dehydrated with 50, 75 and $100 \%$ of ethanol, respectively. The fixed cell was dried and palladium-coated using plasma sputter (Quorum, U.S.) and were observed using FESEM (Tescan Mira 3).

2.3c Leakage study: The deleterious potential of test compound on cell membrane was further confirmed by cell leakage analysis. Overnight incubated, S. aureus and E. coli cell cultures were centrifuged for $10 \mathrm{~min}$ at $10,000 \mathrm{rpm}$ and re-suspended in $0.9 \%$ sterile sodium chloride solution. Thereafter, bacterial cultures were exposed to test compound at its $\mathrm{IC}_{50}$ and incubated for $0,4,8,12,16,20$ and $24 \mathrm{~h}$, respectively. Incubated samples were then centrifuged at 10,000 rpm for $30 \mathrm{~min}$. Supernatant so obtained were analyzed at $320 \mathrm{~nm}$ using a UV-Visible spectrophotometer. ${ }^{29}$

2.3d Bacterial growth curve study: Bacterial growth curve study was carried out in accordance to the method reported by Chatterjee et al. Growth pattern of overnightcultured bacterial suspension of E. coli and S. aureus was observed in presence and absence of test compound by measuring their optical density (OD) at $600 \mathrm{~nm}$ for $24-\mathrm{h}$. All sets were performed in triplicates and averaged. ${ }^{30}$

\subsection{Molecular docking}

Molecular docking provides an insight of receptor ligand interactions. For the molecular docking study, Dihydrofolate reductase (PDB ID-4XE6) from S. aureus was obtained from 

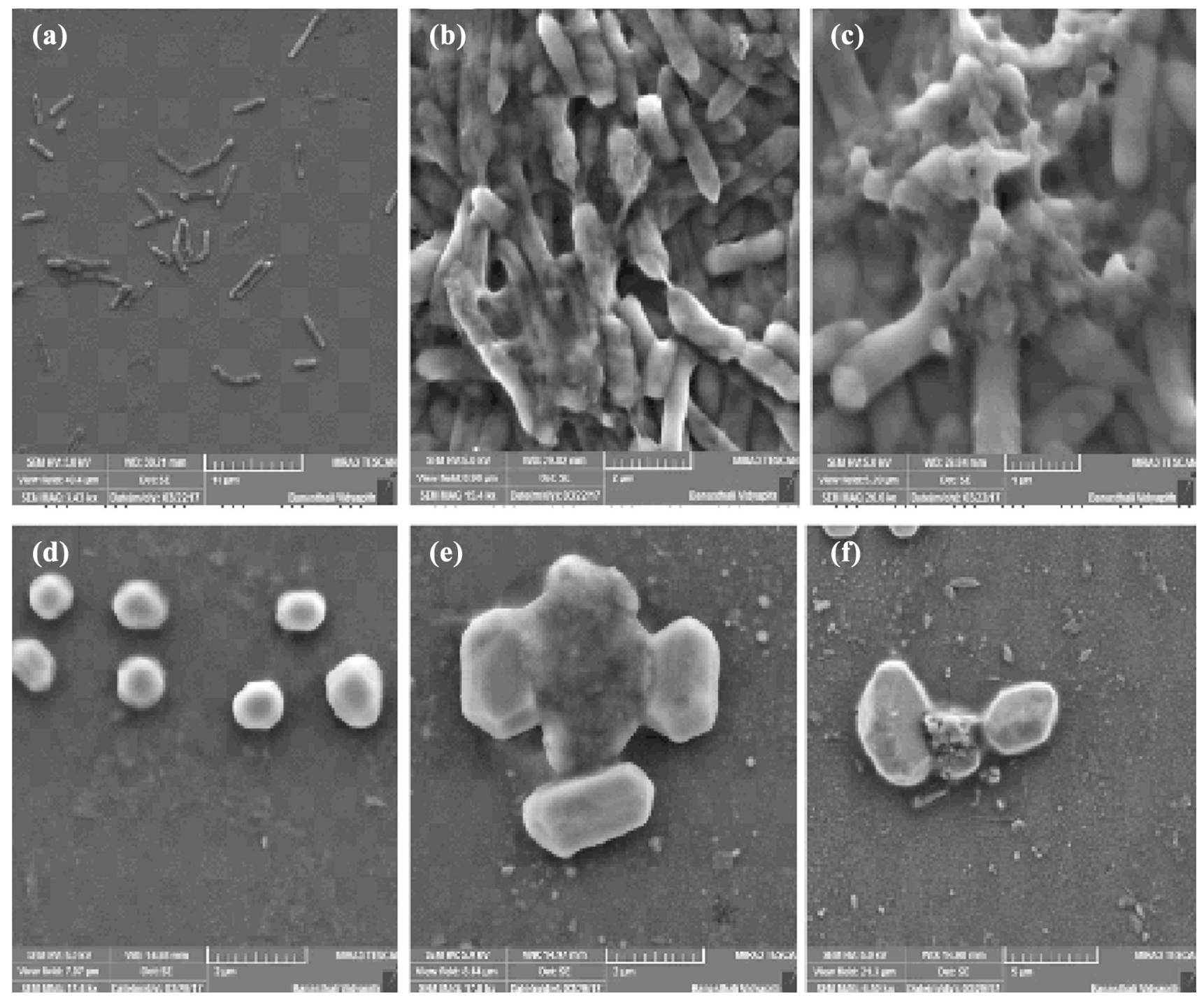

Figure 1. Field emission scanning electron micrographs of $E$. coli $(\mathbf{a}, \mathbf{b}, \mathbf{c})$ and $S$. aureus $(\mathbf{d}, \mathbf{e}, \mathbf{f})$. (a) and $(\mathbf{d})$ are untreated bacterial cells; $(\mathbf{b}, \mathbf{c}, \mathbf{e}$ and $\mathbf{f})$ are bacterial cells after treatment with compound $\mathbf{6}$ at their respective $\mathrm{IC}_{50}$.

the Protein Data Bank. Argus Lab 4.0 docking software was used for the docking study for finding the mode of corresponding interactions of the test compound and the target. Prior to study, water molecules along with lower occupancy residues have been eliminated to avoid any interruption of solvent during docking of the ligand. Binding interactions such as H-bond, van der Wall and hydrophobic interactions clearly demonstrate possible proximity of ligands with receptor. Pymol 1.3 software was used to find the protein-ligand interaction. ${ }^{31}$

\section{Results and Discussion}

\subsection{Chemistry}

Dimethylamino methylene ketoneintermediates ( 2 and 8), were prepared by the reaction of benzoylacetonitrile (1) and pyruvonitrile (7), respectively, with
DMF. DMA (Schemes 1 and 2). ${ }^{32,33}$ Formation of dimethylaminomethylene ketone (2) from (1) was confirmed by their ${ }^{1} \mathrm{H}$ NMR spectra, which showed downfield singlet at $\delta 6.64$ for one proton attached with carbon of $\alpha, \beta$-unsaturated ketone structure and one sharp singlet at $\delta 3.60$ for 6 protons of $\mathrm{CH}_{3}$ group attached with $\mathrm{CHN}\left(\mathrm{CH}_{3}\right)_{2}$. Similarly the structure of compound $\mathbf{8}$ was established. The nitrile bearing 1,5-benzodiazepine moieties 4 and 9 were formed by the cyclocondensation of o-phenylenediamine $\mathbf{3}$ with the nitrile bearing intermediates $\mathbf{2}$ and $\mathbf{8}$, respectively. The formation of benzodiazepine ring was established on the basis of one upfield singlet at $\delta 4.14$ for one proton of $\mathrm{NH}$ and a multiplet at $\delta$ 7.55-6.89 for protons of benzene ring.

Amidoximes $\mathbf{5}$ and $\mathbf{1 0}$ were formed by the reaction of hydroxylamine hydrochloride and base with compounds $\mathbf{4}$ and $\mathbf{9}$, respectively. The cycloaddition reaction 

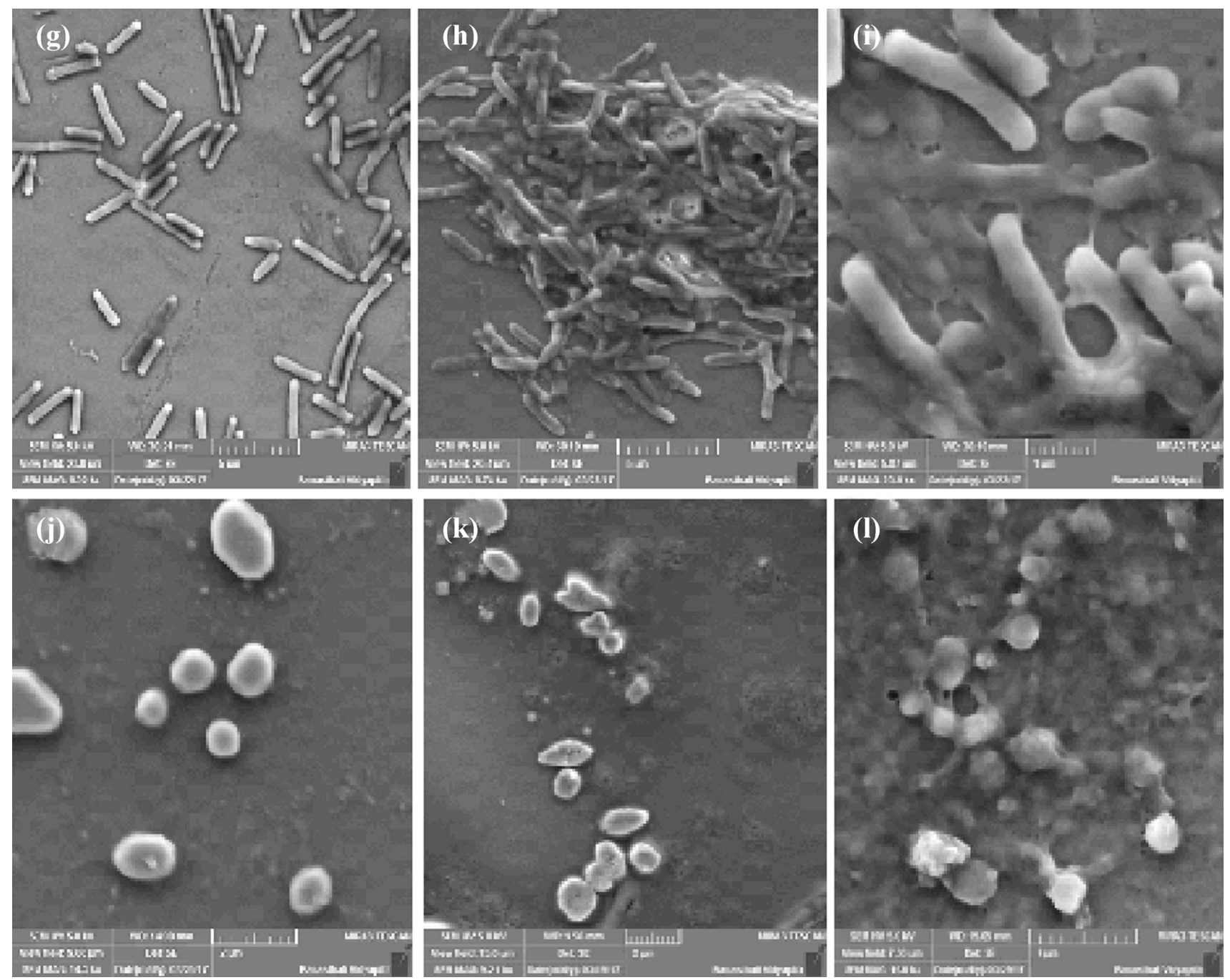

Figure 2. Field emission scanning electron micrographs of $E$. coli $(\mathbf{g}, \mathbf{h}, \mathbf{i})$ and $S$. aureus $(\mathbf{j}, \mathbf{k}, \mathbf{l})$. $(\mathbf{g})$ and $(\mathbf{j})$ are untreated bacterial cells; $(\mathbf{h}, \mathbf{i}, \mathbf{k}$ and $\mathbf{l})$ are bacterial cells after treatment with compound $\mathbf{1 1}$ at their respective $\mathrm{IC}_{50}$.

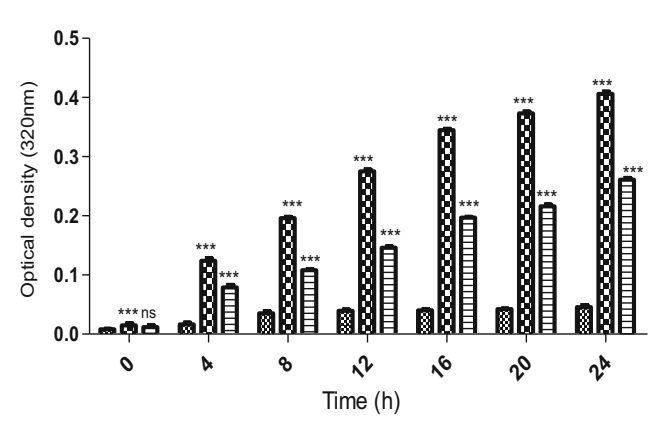

Control $\quad$ Comp $6(150 \mu \mathrm{g} / \mathrm{ml})$

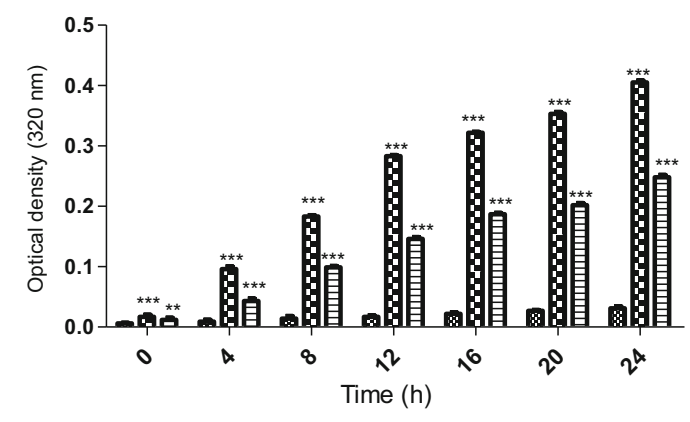

Control Comp $6(100 \mu \mathrm{g} / \mathrm{ml})$ Comp $11(150 \mu \mathrm{g} / \mathrm{ml})$

Figure 3. Effect of test compounds on cell leakage of E. coli and S. aureus.

of amidoximes $\mathbf{5}$ and $\mathbf{1 0}$ with dimethyl acetylenedicarboxylate (DMAD) ${ }^{34}$ induced a series of tandem C-O and C-N coupling sequence prior to a concomitant cyclocondensation of the formed intermediate to give $\mathbf{6}$ and
11, respectively, as outlined in Schemes 1 and 2. The catalyst DABCO (1,4-diazabicyclo[2.2.2] octane $)^{35}$ was used to augment the yield of the product. A peak at $1742 \mathrm{~cm}^{-1}$ in the IR spectrum of compound 6 indicated 


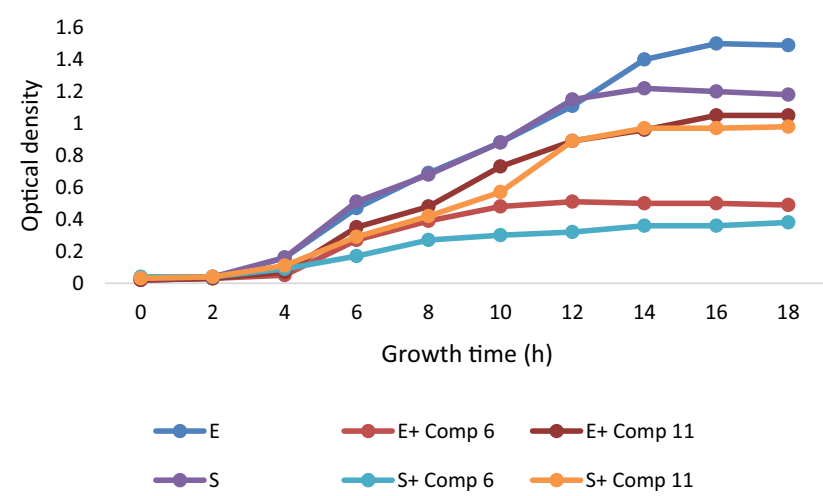

Figure 4. Effect of test compounds on the growth pattern of $E$. coli and $S$. aureus.

$\mathrm{C}=\mathrm{O}$ of ester group. Two singlets at $\delta 12.36, \delta 5.56$ in ${ }^{1} \mathrm{H}$ NMR spectrum confirms the presence of two $-\mathrm{OH}$ groups and a triplet at $\delta 3.83$ clearly indicated the presence of methyl part of the ester group in compound
6. Similarly the structure of compound $\mathbf{1 1}$ was established.

A probable mechanism for the formation of compound $\mathbf{6}$ is presented in Scheme 3. The advent of this one-pot technique in providing the access to diversely functionalized pyrimidine derivatives from a nitrile substrate is an innovative synthetic tool to incorporate these medicinally valuable scaffolds on the 1,5benzodiazepine nucleus.

\subsection{Antibacterial study}

3.2a Determination of half maximal inhibitory concentration $\left(I C_{50}\right)$ : The minimum inhibitory concentration $\left(\mathrm{IC}_{50}\right)$ was screened against Gram-positive bacterium ( $S$. aureus) and Gram-negative bacterium ( $E$. coli). The test compound (6) showed potent inhibitory activity against $S$. aureus and $E$. coli with $\mathrm{IC}_{50}$ values

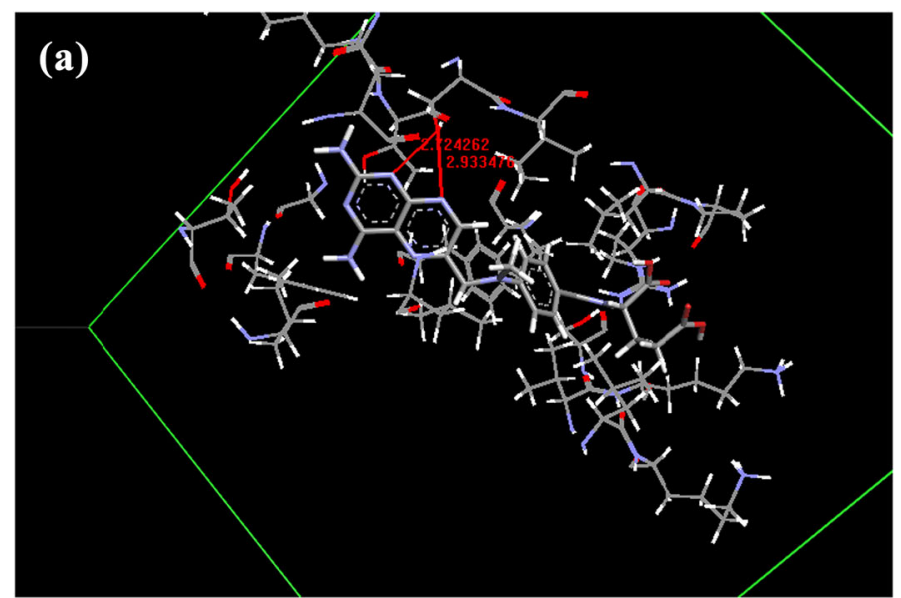

(b)
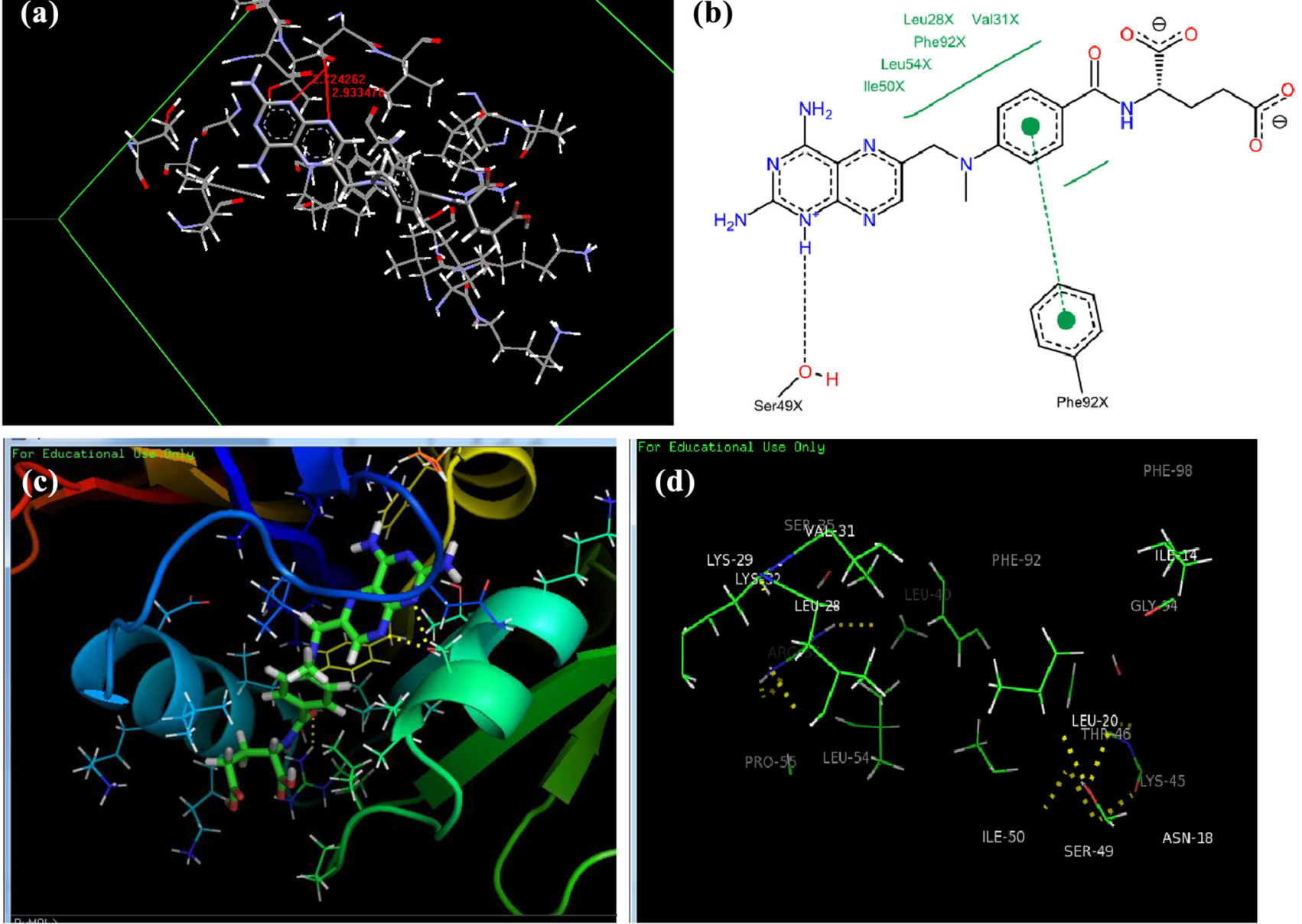

Figure 5. Binding mode for compound MTX docked and minimized in the DHFR binding pocket, with residues involved in its recognition. Molecular docking structure and ligand protein binding sites of MTX- (a) Best possible pose of compound MTX (boll and stick structure) showing hydrogen bond (red color line) and bond distance; (b) 2D pose view; (c) and (d) 3D pose views of docked MTX. 


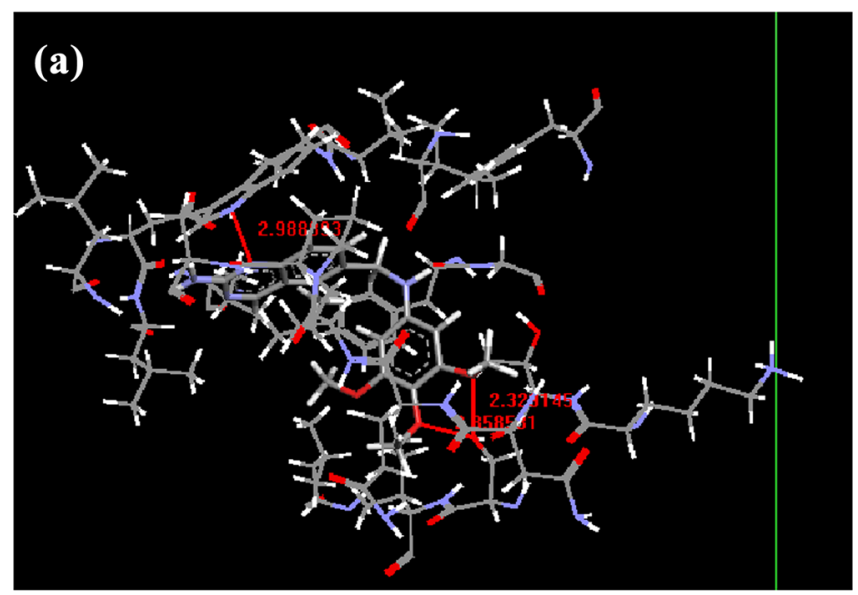

(b)
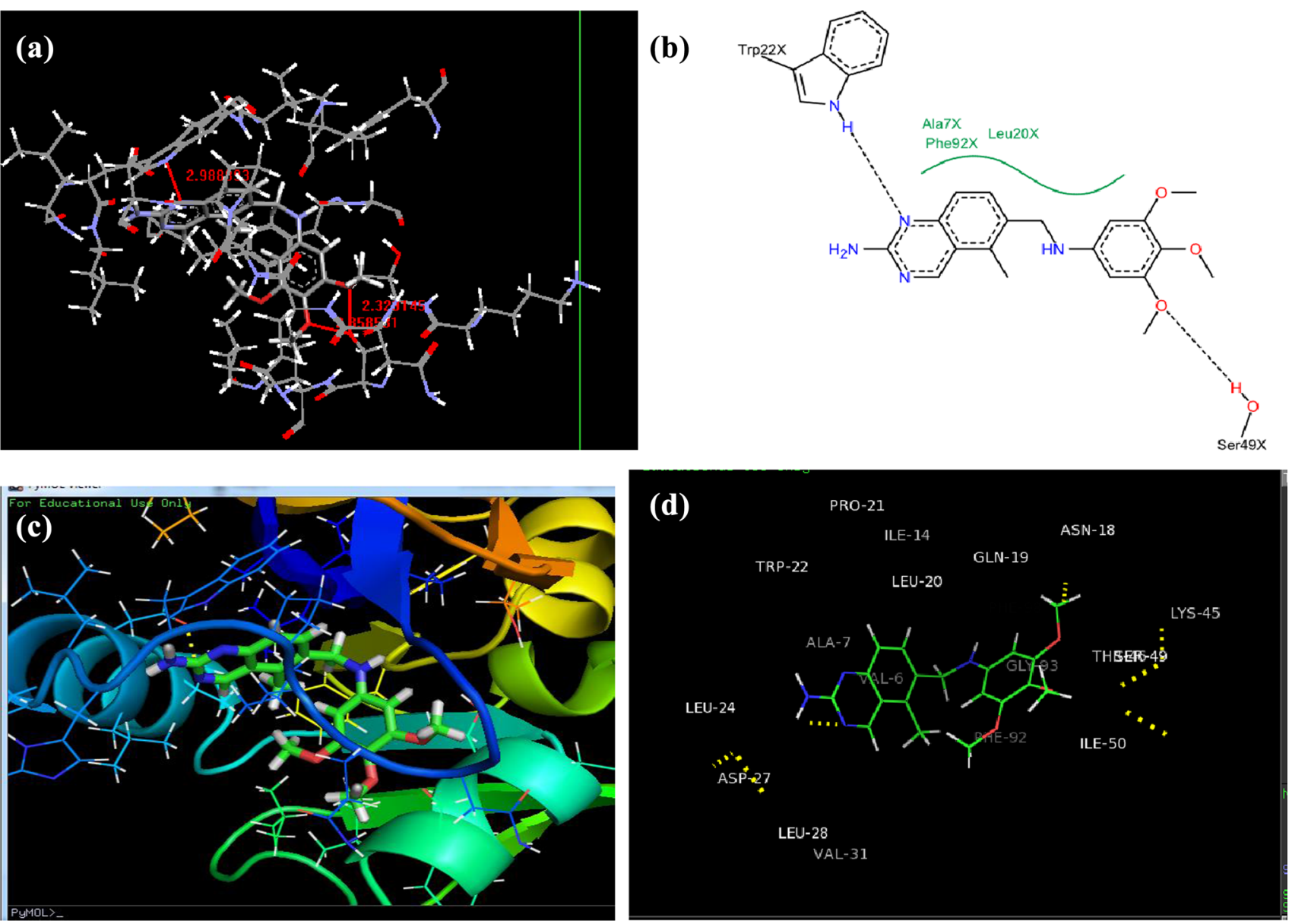

Figure 6. Binding mode for compound TMQ docked and minimized in the DHFR binding pocket, with residues involved in its recognition. Molecular docking structure and ligand protein binding sites of TMQ. (a) Best possible pose of compound TMQ (boll and stick structure) showing hydrogen bond (red color line) and bond distance; (b) 2D pose view; (c) and (d) 3D pose views of docked TMQ.

$200 \mu \mathrm{g} / \mathrm{mL}$ and $300 \mu \mathrm{g} / \mathrm{mL}$ respectively. While $\mathrm{IC}_{50}$ values for compound 11 against $S$. aureus and $E$. coli were $300 \mu \mathrm{g} / \mathrm{mL}$ and $300 \mu \mathrm{g} / \mathrm{mL}$ respectively.

\section{2b Field emission scanning electron microscopy} (FESEM) study: FESEM study was carried out to understand the effect of test compounds $\mathbf{6}$ and $\mathbf{1 1}$ on morphology of both Gram-positive ( $S$. aureus) and Gram-negative (E. coli) bacterium cell wall. FESEM images revealed that cell surface of control (untreated, E. coli) was smooth and exhibited normal morphological characteristics (Figures 1a and $2 \mathrm{~g}$ ), whereas treatment with test compound caused a significant damage of the cell wall that lead to membrane disintegration (Figures $1 \mathrm{~b}, 1 \mathrm{c}, 2 \mathrm{~h}$ and $2 \mathrm{i}$ ). Similar pattern of results was obtained in S. aureus sample- (Figures 1e, 1f, 2k and 2l) in comparison to the control (untreated) bacterial cells (Figures $1 \mathrm{~d}$ and $2 \mathrm{j}$ ). These results clearly demonstrated that the test compound caused bacterial lysis via its membrane damaging effects on both bacterial samples.
Results were found to be in agreement to previously published studies. ${ }^{36}$

3.2c Leakage study: The leakage of nucleotides and their integral components from compromised bacterial cells was assessed by plotting the optical density with respect to exposure time at $320 \mathrm{~nm}$. Results of the study showed that rate of leakage of cell nucleotides increased with increase in exposure duration through ruptured cell membrane of treated bacterial strains as compared to controls (Figure 3 ). It was realized that test compounds $\mathbf{6}$ and $\mathbf{1 1}$ caused bacterial lysis via membrane damaging effect that lead to consistent leakage of essential metabolites from bacterial cells. Findings of the study were found in agreement to previously published reports. ${ }^{28}$

3.2d Bacterial growth curve study: Effect of the test compound was observed on the growth curve of different bacterial species (E. coli and S. aureus) was studied. Control cell showed a normal pattern of growth with lag 

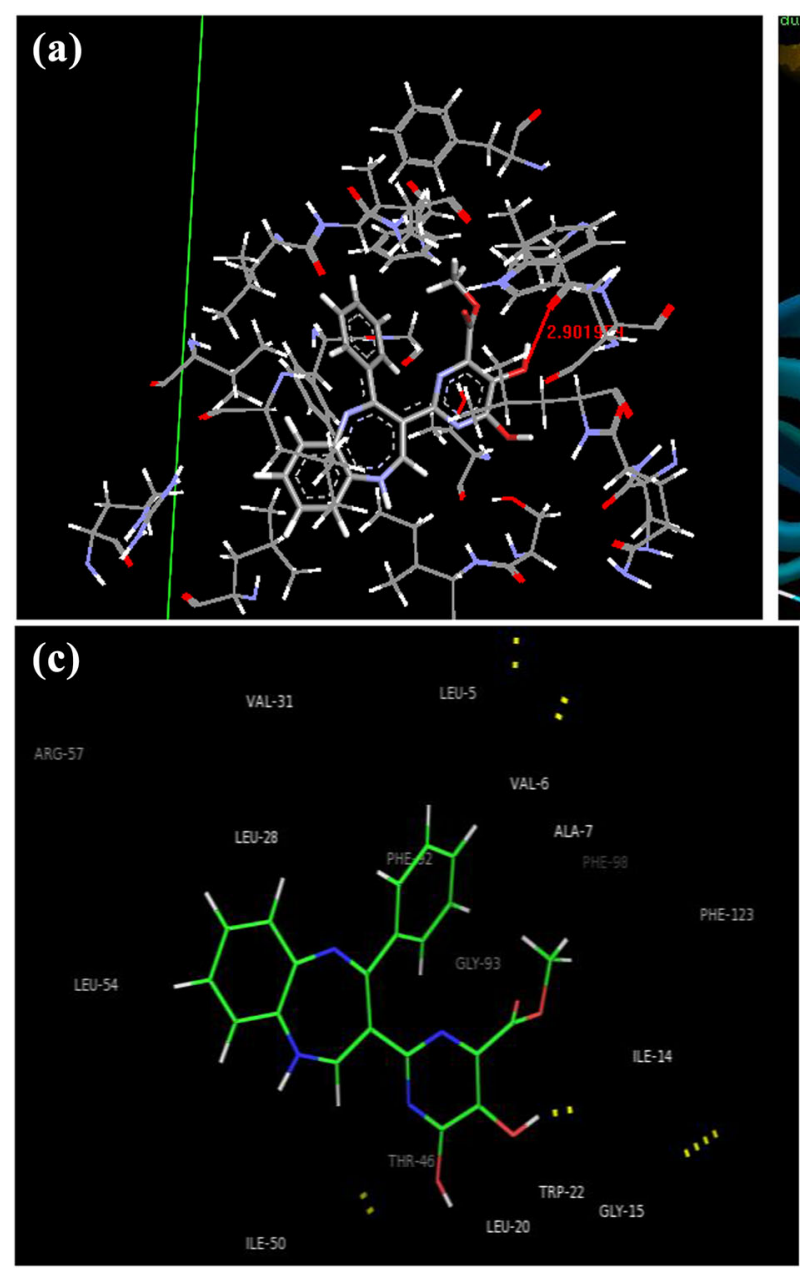

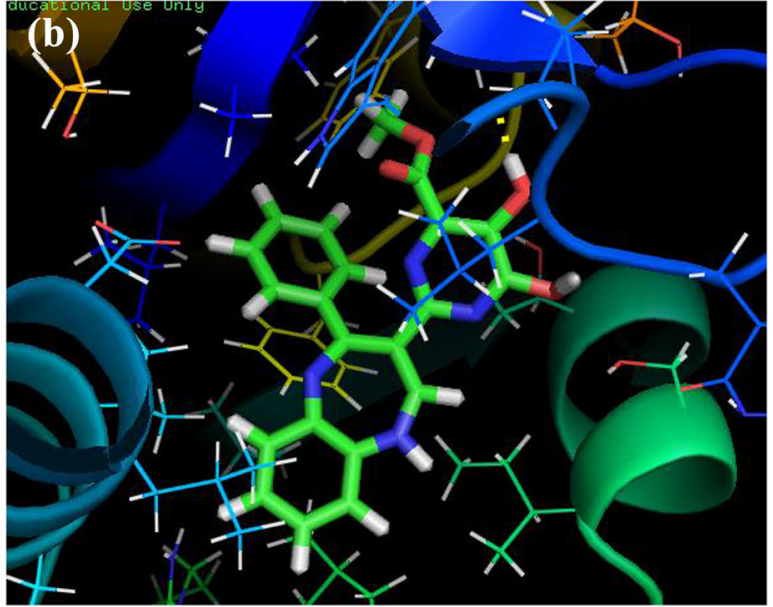

(d)

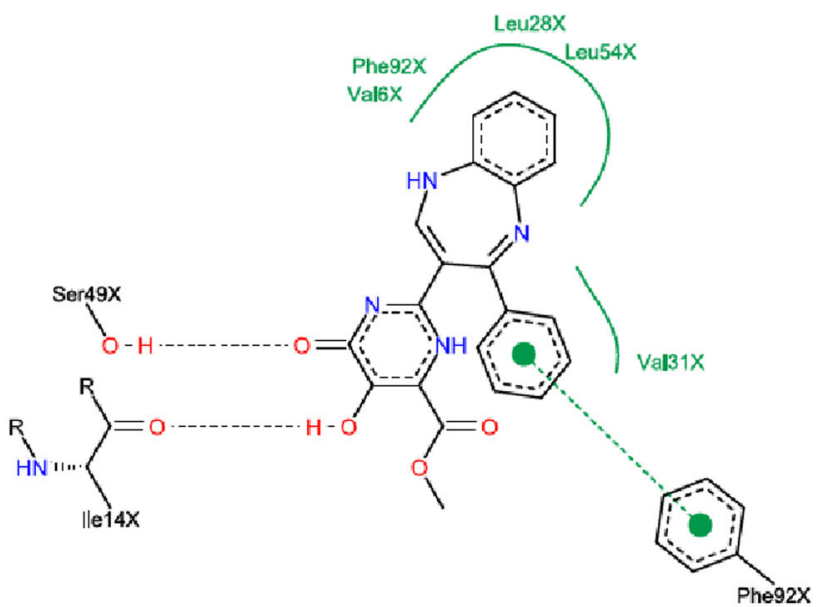

Figure 7. Binding mode for Compound $\mathbf{6}$ docked and minimized in the DHFR binding pocket, with residues involved in its recognition. Molecular docking structure and ligand protein binding sites of Compound $\mathbf{6}$. (a) Best possible pose of $\mathbf{6}$ (boll and stick structure) showing hydrogen bond (red color line) and bond distance; (b) and (c) 3D pose views of docked 6; and (d) $2 \mathrm{D}$ pose view.

phase of $4 \mathrm{~h}$ and $\log$ phase of $8-10 \mathrm{~h}$ whereas presence of test compounds (6 and 11) at their $\mathrm{IC}_{50}$ remarkably altered normal pattern of growth with significant decrease in lag phase to 5-6 h with respect to control against both the strains which directly indicated antibacterial potential of test compounds (Figure 4).

\subsection{Molecular docking}

The docking study gives an idea about interaction between test compound and target protein. In the present study, test compound was docked over targeted protein dihydrofolate reductase from $S$. aureus (PBD ID-4XE6). Test compound showed different modes of binding with amino acids located at active site of dihydrofolate reductase. For this, fitting at the enzyme pocket in a highly comparable manner to the previously available classical and non-classical dihydrofolate inhibitors like Methotrexate (MTX) and Trimetrexate (TMQ) was studied (Figures 5, 6, 7, 8) when compared with highly active compound 6 (Figure 7).

Compounds 6 and 11, exhibited considerable docking results with a score of 10.26 and $-8.69 \mathrm{kcal} / \mathrm{mol}$ when compared with the MTX and TMQ (Table 1). From 2D pose view, it clearly shows that Phe92 amino acid is a common residue which involved in the hydrogen bond formation in compounds $\mathbf{6}$ and $\mathbf{1 1}$ as well in the previously available classical and non-classical dihydrofolate inhibitors (MTX) and (TMQ).

In the docking study, it was found that the oxygen and hydrogen atom of pyrimidine ring in test compound $\mathbf{6}$ was available for the formation of hydrogen bond with different amino groups of taken PDB file with specific bond distance. Compound 6 has been found in firm proximity within the active site of the receptor through $\mathrm{H}$ bond interactions with Ser49, Ile14, Val6, Val31, Leu28 and Leu54 amino acid residues. These amino acids make a cascade to facilitate binding and holding of the test 

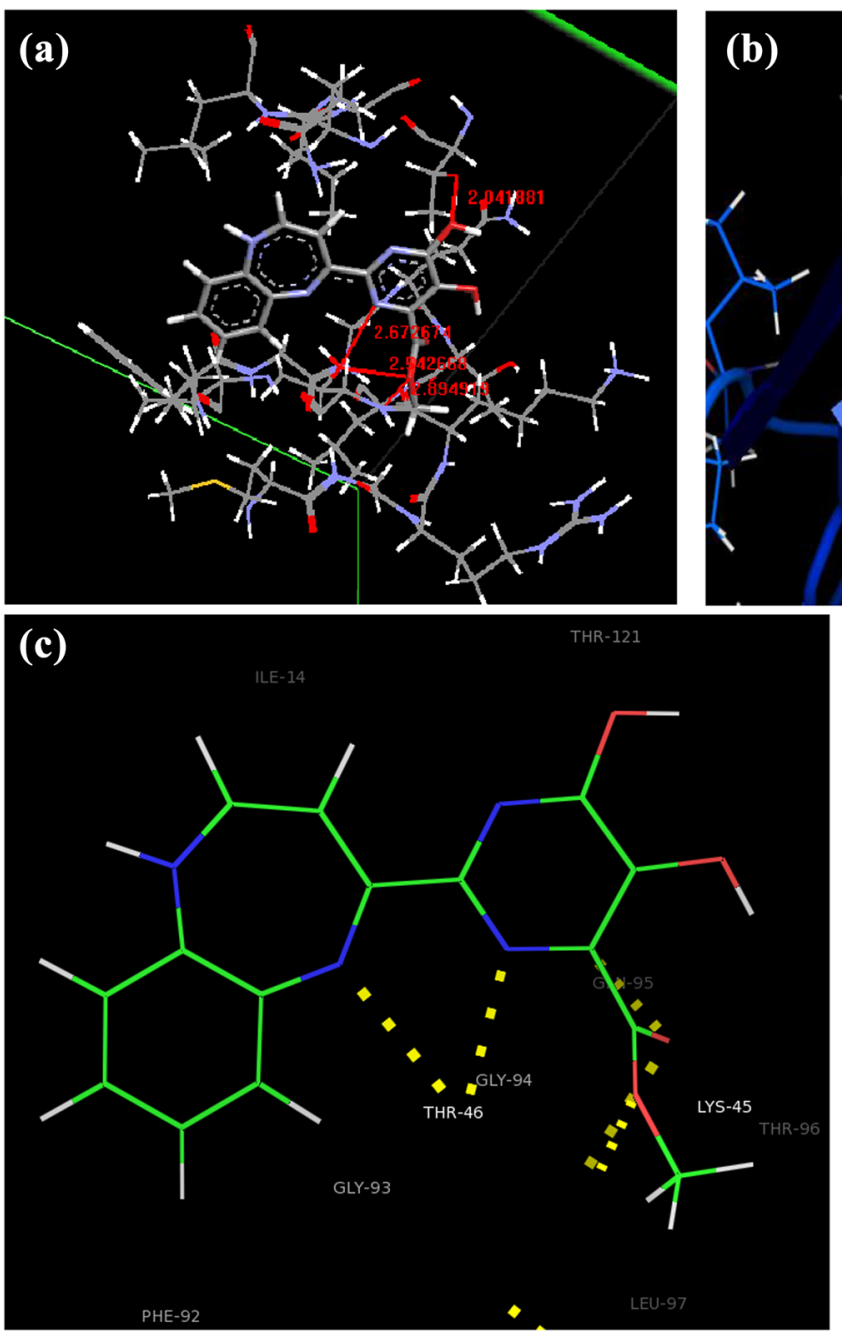

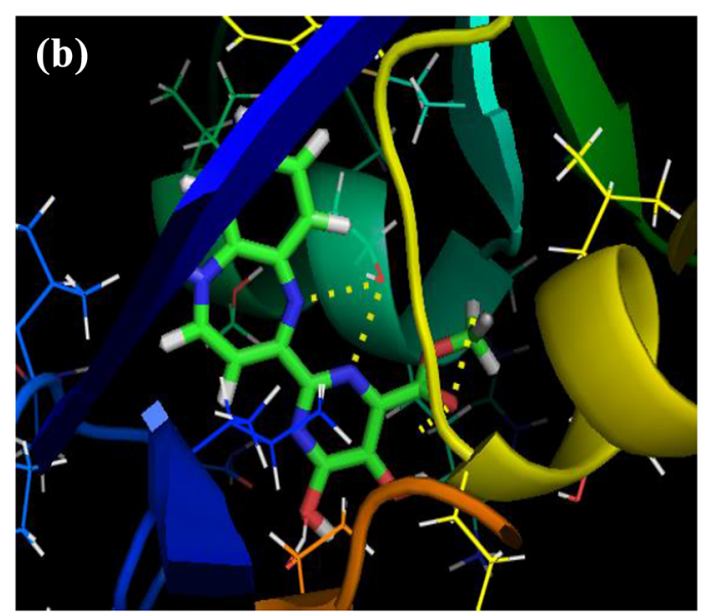

(d)

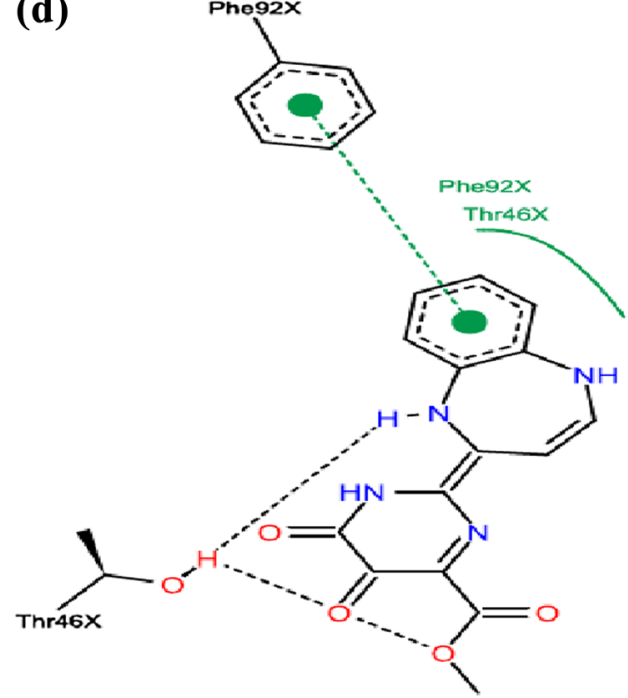

Figure 8. Binding mode for compound $\mathbf{1 1}$ docked and minimized in the DHFR binding pocket, with residues involved in its recognition. Molecular docking structures and ligand protein binding sites of Compound 11. (a) Best possible pose of compound 11 (boll and stick structure) showing hydrogen bond (red color line) and bond distance; (b) and (c) 3D pose views of docked compound 11; (d) 2D pose view.

Table 1. Docking parameters for ligand DHFR interaction.

\begin{tabular}{lccc}
\hline \multirow{2}{*}{ Ligand } & \multirow{2}{*}{ Docking score $\Delta \mathrm{G}(\mathrm{kcal} / \mathrm{mol})$} & \multicolumn{2}{c}{ Atoms and residue of receptor involved in hydrogen bonding } \\
\cline { 3 - 4 } & & Atoms & Residues \\
\hline Parent Compound MTX & -8.72 & $\mathrm{~N}$ & Ser49 \\
Parent Compound TMQ & -8.29 & $\mathrm{O}$ & Ser49 \\
Compound 6 & -10.26 & $\mathrm{O}$ & Ser49 \\
Compound 11 & -8.69 & $\mathrm{O}-\mathrm{H}$ & Ile14 \\
\hline
\end{tabular}

compound in the active site of dihydrofolate reductase protein. Results of molecular docking study indicated that compound $\mathbf{6}$ has dihydrofolate reductase inhibitory potential.

The residues which participated in hydrogen bond formation with compound $\mathbf{6}$ were similar to MTX and TMQ whereas a distinct set of amino acid residues of the DHFR pocket was obtained with compound $\mathbf{1 1}$. Low docking score of compound $\mathbf{1 1}$ may be attributed to dissimilar interaction when compared to compound $\mathbf{6}$ and standard. However, it showed interesting hydrogen bonding interaction with $\mathrm{OCH}_{3}$ and ring $\mathrm{N}-\mathrm{H}$ with $\mathrm{OH}$ of Thr46 amino acid of the target enzyme (Figure 8). 


\section{Conclusion}

In conclusion, a reliable and eco-friendly domino approach was used to synthesize bioactive pyrimidine derivatives of 1,5-benzodiazepines. IC $_{50}$ of synthesized compounds demonstrated strong antibacterial activities against $S$. aureus and $E$. coli. Furthermore, the mode of action was examined through FE-SEM imaging which clearly indicated membrane damaging effects of compounds 6 and 11. In addition, molecular docking studies suggested that test compounds may act through bacterial DHFR inhibition. Further in-depth study is required to confirm exact mode of action of the test compound and its usage at clinical level.

\section{Supplementary Information (SI)}

Characterization data including FTIR, ${ }^{1} \mathrm{H}$ NMR, ${ }^{13} \mathrm{C}$ NMR and Mass spectra, results of docking and antibacterial studies are presented in Supplementary Information, available at www.ias.ac.in/chemsci.

\section{Acknowledgements}

The authors are deeply grateful for the financial support provided by Department of Science and Technology (DST), New Delhi under the CURIE (Consolidation of University Research for Innovation and Excellence in Women Universities) Scheme and MHRD, New Delhi, Under Training and Research in Frontier Areas of Science and Technology (FAST) Scheme. Authors are also thankful to Dr. Saral Kumar Gupta, Head, Department of Physics, Banasthali Vidyapith, Banasthali, Rajasthan, India for extending FE-SEM facility.

\section{Compliance with ethical standards}

Conflict of interest The authors declare that they have no conflict of interest.

\section{References}

1. Tietze L F and Rackelmann N 2004 Domino reactions in the synthesis of heterocyclic natural products and analogs Pure Appl. Chem. 761967

2. (a) Kaur N and Kishore D 2014 Synthetic strategies applicable in the synthesis of privileged scaffold: 1,4benzodiazepine Synth. Commun. 44 1375; (b) Khodairy A, El-Sayed A M, Salah H, Abdel-Ghany H 2007 Synthesis of Spiro 1,5-Benzodiazepine Attached with Different Heterocyclic Moeities Synth. Commun. 373245

3. Sarro G D, Ferreri G, Gareri P, Russo E, Sarro A D, Gitto R and Chimirri A 2003 Comparative anticonvulsant activity of some 2,3-benzodiazepine derivatives in rodents Pharmacol. Biochem. Behav. 74595

4. Kusanur R A, Ghate M and Kulkarni M V 2004 Synthesis of spiro[indolo-1,5-benzodiazepines] from 3-acetyl coumarins for use as possible antianxiety agents J. Chem. Sci. 116265

5. Kumar R and Joshi Y C 2007 Synthesis, spectral studies and biological activity of 3H-1, 5-benzodiazepine derivatives Arkivoc. 13142

6. Nawrocka W, Sztuba B, Opolski A, Wietrzyk J, Kowalska M W and Głowiak T 2001 Synthesis and antiproliferative activity in vitro of novel 1,5 - benzodiazepines Arch. Pharm. Med. Chem. 3343

7. Salve P S and Mali D S 2013 1,5-Benzodiazepine: A versatile pharmacophore Int. J. Pharm. Bio. Sci. 4345

8. Braccio M D, Grossi G, Roma G, Vargiu L, Mura M and Marongiu M E 2001 1,5-Benzodiazepines. Part XII. Synthesis and biological evaluation of tricyclic and tetracyclic 1,5-benzodiazepine derivatives as nevirapine analogues Eur. J. Med. Chem. 36935

9. Tarnawa I, Farkas S, Berzsenyi P, Pataki A and Andrasi F 1989 Electrophysiological studies with a 2,3benzodiazepine muscle relaxant: GYKI 52466 Eur. J. Pharmacol. 167193

10. Atwal K S, Bergey J L, Hedberg A and Moreland S 1987 Synthesis and biological activity of novel calcium channel blockers: 2,5-dihydro-4-methyl-2-phenyl1,5-benzothiazepine-3-carboxylic acid esters and 2,5-dihydro-4-methyl-2-phenyl-1,5-benzodiazepine-3carboxylic acid esters J. Med. Chem. 30635

11. Bock M G, DiPardo R M, Evans B E, Rittle K E, Veber D F, Freidinger R M, Chang R S L and Lotti V J 1988 Cholecystokinin antagonists. Synthesis and biological evaluation of 4-substituted 4H-[1,2,4]triazolo[4,3a][1,4]benzodiazepines J. Med. Chem. 31176

12. Aranapakam V, Albright J D, Grosu G T, Santos E G D, Chan P S, Coupet J, Ru X, Saunders T and Mazandarani H 1999 5- fluoro-2-methyl-N[5H-pyrrolo[2,1-c][1,4]benzodiazepine-10 $(11 \mathrm{H})$-yl carbonyl)-2-pyridinyl]benzamide (CL-385004) and analogs as orally active arginine vasopressin receptor antagonist Bioorg. Med. Chem. Lett. 91737

13. Miyazaki Y, Matsunaga S, Tang J, Maeda Y, Nakano M, Philippe R J, Shibahara M, Liu W, Sato H, Wang L and Nolte RT 2005 Novel 4-amino-furo[2,3-d]pyrimidines as Tie-2 and VEGFR2 dual inhibitors Bioorg. Med. Chem. Lett. 152203

14. Yadav S K, Patil S M M and Gupta S K 2012 Synthesis of 11-pyrimidine ring incorporated analogues of pyrrolo [2,1-C][1,4]-benzodiazepines Novel. Sci. Int. J. Pharm. Sci. 1329

15. Ballell L, Robert A F, Chung G A C and Young R 2007 New thiopyrazolo[3,4-d]pyrimidine derivatives as antimycobacterial agents Bioorg. Med. Chem. Lett. 171736

16. El-Gazzar A B A and Hafez H N 2009 Synthesis of 4-substituted pyrido[2,3-d]pyrimidin-4(1H)-one as analgesic and anti-inflammatory agents Bioorg. Med. Chem. Lett. 193392

17. Sondhi S M, Singh N, Johar M and Kumar A 2005 Synthesis, anti-inflammatory and analgesic activities evaluation of some mono, bi and tricyclic pyrimidine derivatives Bioorg. Med. Chem. 136158

18. Kamdar N R, Haveliwala D D, Mistry P T and Patel S K 2010 Design synthesis and in-vitro evaluation of anti tubercular and anti-microbial activity of some novel pyrano pyrimidines Eur. J. Med. Chem. 455056 
19. Corte B L D 2005 From 4,5,6,7-Tetrahydro-5methylimidazo[4,5,1-jk](1,4)benzodiazepine-2(1H)one (TIBO) to Etravirine (TMC125): Fifteen years of research on non-nucleoside inhibitors of HIV-1 reverse transcriptase J. Med. Chem. 481689

20. Chatterjee T, Chatterjee B K, Majumdar D and Chakrabarti P 2015 Antibacterial effect of silver nanoparticles and the modeling of bacterial growth kinetics using a modified Gompertz model Biochim. Biophys. Acta 1850299

21. Abdel-Hafez N A, Ashraf, Mohamed M, Amr A E G E and Abdalla M A 2009 Antiarrhythmic activities of some newly synthesized tricyclic and tetracyclic thienopyridine derivatives Sci. Pharm. 77539

22. Ivachtchenko A V, Golovina E S, Kadieva M G, Kysil V M, Mitkin O D, Tkachenko S E and Okun I M 2011 Synthesis and structure-activity relationship (SAR) of (5,7-disubstituted 3-phenylsulfonylpyrazolo[1,5-a]pyrimidin-2-yl)-methylamines as potent serotonin 5-HT6 receptor (5-HT6R) antagonistsJ. Med. Chem. 548161

23. Sahu M and Siddiqui N 2016 A Review on biological importance of pyrimidines in the new era Int. J. Pharm. Sci. 88

24. Al-Harbi N O, Bahashwan S A, Fayed A A, Aboonq M S and Amr A E E 2013 Anti-parkinsonism, hypoglycemic and anti-microbial activities of new poly fused ring heterocyclic candidatesInt. J. Biol. Macromol. 57165

25. Selvam T P, James C R, Dniandev P V and Valzita S K 2012 A mini review of pyrimidine and fused pyrimidine marketed drugs Res. Pharm. 201

26. Al-Omary F A, Hassan G S, El-Messery S M, Nagi M N, Habib E S and El-Subbagh H I 2013 Non-classical antifolates. Part 2: synthesis, biological evaluation, and molecular modeling study of some new 2,6-substitutedquinazolin-4-ones Eur. J. Med. Chem. 6333

27. Frutos R P, Wei X, Patel N D, Tampone T G, Mulder J A, Busacca C A and Senanayake C H 2013 One-pot synthesis of 2,5-disubstituted pyrimidines from nitriles J. Org. Chem. 785800
28. Abdelrazek F M and Bahbouh M S 2012 Recent advances in the chemistry of nitriles and enaminonitriles JJEES 4 47

29. Ghosh S, Indukuri K, Bondalapati S, Saikia A K and Rangan L 2013 Unveiling the mode of action of antibacterial labdane diterpenes from Alpinia nigra (Gaertn.) B. L. Burtt seeds Eur. J. Med. Chem. 66101

30. Punia K, Punia A, Chatterjee K, Mukherjee S, Fata J, Banerjee P, Raja K and Yang N L 2017 Rapid bactericidal activity of an amphiphilic polyacrylate terpolymer system comprised of same-centered comonomers with 2-carbon and 6-carbon spacer arms and an uncharged repeat unit $R S C A d v .710192$

31. Zhou X, Lin K, Ma X, Chui W K and Zhou W 2017 Design, synthesis, docking studies and biological evaluation of novel dihydro-1,3,5-triazines as human DHFR inhibitors Eur. J. Med. Chem. 1251279

32. Shanab F A A, Mousa S A S, Eshak E A, Sayed A Z and Harrasi A A 2011 Dimethylformamide dimethyl acetal (DMFDMA) in heterocyclic synthesis: Synthesis of polysubstituted pyridines, pyrimidines, pyridazine and their fused derivatives Int. J. Org. Chem. 1207

33. Pareek A, Rani P, Agarwal A, Shekhawat S and Kishore D 2013 Synthesis of benzoazepino incorporated analogues of 1, 5-benzodiazepine of medicinal interest Int. J. Chem. Pharm. Sci. 444

34. Humphrey G R, Pye P J, Zhong Y L, Angelaud R, Askin D, Belyk K M, Maligres P E, Mancheno D E, Miller R A, Reamer R A and Weissman S A 2011 Development of a second generation, highly efficient manufacturing route for the HIV integrase inhibitor raltegravir potassium $\mathrm{Org}$. Process. Res. Dev. 1573

35. Ngwerume S and Camp J E 2010 Synthesis of highly substituted pyrroles via nucleophilic catalysts J. Org. Chem. 756271

36. Koyama S, Yamaguchi Y, Tanaka S and Motoyoshiya J 1997 A new substance (Yoshixol) with an interesting antibiotic mechanism from wood oil of Japanese traditional tree (Kiso-Hinoki), Chamaecyparis Obtusa Gen. Pharmacol. 28797 